ORIGINAL ARTICLE

\title{
GENDER DISPARITY IN RISK FACTORS FOR CHRONIC KIDNEY DISEASE IN A RURAL COMMUNITY IN SOUTHERN NIGERIA
}

\section{Okoye OC}

Department of Internal Medicine. Delta State University, A braka. Nigeria

Correspondences and reprint request to: D r O koye $O C$, Department of Internal Medicine, Delta State University, P.M.B. 1. Abraka, Delta State, Nigeria

Email: ogonwosu2002@yahoo.com, Tel: +2348023443621

\begin{abstract}
Background: : Theevidence for gender disparity in prevalence of CKD is conflicting; while some studies report male preponderance, others have report female preponderance or no difference. Reasons for gender disparities in CKD prevalence may berelated to differences in theoccurrence of risk factors across the gender, amongst other factors. This study was to determine gender disparities in the risk factors for CKD. M ethod: This study is based on data from a community based cross-sectional study carried out in Ogbona, a rural community in Southern Nigeria. The WHO STEPS for surveillance of chronic diseases risk factors and chronic disease-specific morbidity and mortality questionnairewas adapted for this study. Four hundred and seventy-six participants were selected from 142 housing units in the community using multi-stage cluster sampling. Clinical examinations and laboratory investigations including serum creatinine, and urinalysis were performed. Results: Majority of participants were females (66.2\%). CKD was commoner in females compared to males ( $14.3 \%$ vs. $12.7 \%, \mathrm{P}=0.06)$. Morefemales than males had high body fat percentages ( $65.7 \%$ vs. $40.9 \%, P=<0.0001)$, high waist-hip ratio $(99.7 \%$ vs $73.3 \%$, $\mathrm{P}=<0.0001)$ and central obesity $(43.1 \%$ and $4.3 \% \mathrm{P}=<0.0001)$. M ore males compared to females used alcohol ( $56 \%$ vs. $9.2 \%, P=<0.0001)$, were overweight $(42.2 \%$ vs $28.9 \%, P=0.004)$, and had proteinuria $(6.2 \%$ vs $2.5 \%, P=0.054)$. The odds of females having central obesity are 16.7 times the odds of males having central obesity; similarly, the odds of females having high BF are 2.7 times the odds of males having high BF. Females had 122 -fold theodds of men having high WHR. The odds of drinking alcohol are $92 \%$ less compared to males. There were no statistically significant gender differences regarding hypertensi on, diabetes mellitus, and use of nephrotoxins (NSAIDS, skin lightening agents, herbal medications). No female smoked cigarettes. Conclusion: This study shows that there is no statistically significant gender difference as regards prevalence of CKD, however several risk factors of CKD show gender disparity. The odds for central obesity, high WHR, high body fat percentages aresignificantly greater in females; whilesmoking, alcohol use, and over weightness, are commoner in males. There were no statistically significant gender differences regarding hypertension, diabetes mellitus, and use of nephrotoxins (NSAIDS, skin lightening agents, herbal medications).
\end{abstract}

KEY WO RD S: Gender disparities, Chronickidney disease, Risk factors, Southern N igeria

\section{INTRODUCTION}

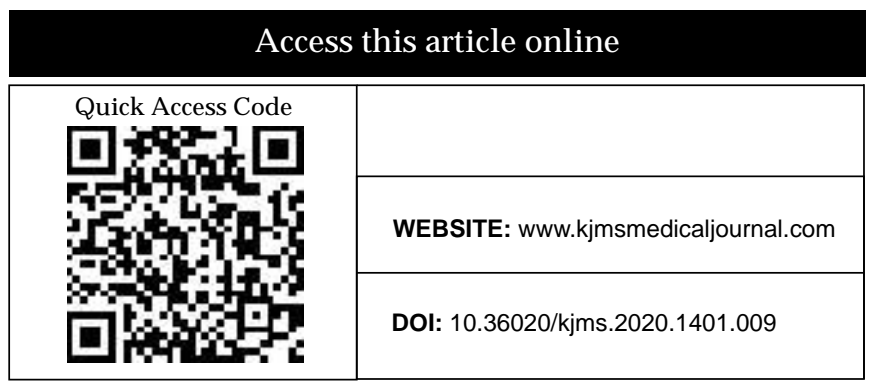

Chronic kidney disease (CKD) is one of the major non-communicable diseases contributing to significant morbidity and mortality globally. A systematic analysis for the Global Burden of Disease Study 2017 reports that the global all-age mortality rate from chronic kidney disease increased $41.5 \%$ from 1990-2017. ${ }^{1}$ The epidemiology of CKD varies from country to 
country, however the global prevalence of allstages of CKD is $9 \%$, with all-age prevalence increasing by $29.3 \%$ from 1990 to 2017. 'The common risk factors for development of CKD include hypertension, diabetes mellitus, glomerulonephritis, autoimmune diseases, urinary tract infections, urinary stones, nephrotoxins and lower urinary tract obstruction. Sub-Saharan Africa is onetheregions with thehighest burdens of CKD, and this has been associated with socioeconomic factors as well as peculiar risk factors of CKD such as infections and exposure to toxins amongstothers. ${ }^{2,3}$

The evidence for gender disparity in prevalence of CKD is conflicting, reasons for this variability in reports may be attributable to socio-demographics of study population, and methodology. Some studies havereported a male preponderance; ${ }^{1,4}$ and this may berelated to the higher prevalence of some risk factors for CKD in the males compared to females, a possiblehormonal protection in females, genetic, geographical, and lifestyle factors. The Global Burden of DiseaseStudy 2017 reported that age-standardised preval ence of CKD stages 1-3 was 1.29 times higher in females compared to males, while age-standardised CKD mortality was higher in males. ${ }^{1}$ Other studies generally report no significant gender predilection in CKD ${ }^{5,6}$, whilethe NHANES and Global Burden of Disease 2016 studies reported a female preponderance. ${ }^{7,8}$ A side from common traditional risk factors for CKD like hypertension and diabetes, pregnancy related AKI (preeclampsia, septic abortion, post-partum haemorrhage) is a major contributor to morbidity and mortality among women of childbearing age, and increases the risk for CKD in survivors. ${ }^{9}$ Some aetiologies of CKD (e.g. autoimmunedisorders) are also commoner in females. The variability of age distribution across studies may influence the gender distribution. Studies in which middle and older age groups predominate may observe more females than males, given that females have a longer lifespan. ${ }^{10}$

Studies have consistently shown that males predominate in the ESRD population in most countries and are at a higher risk of progressive CKD. ${ }^{11-14}$ The preponderance of certain CKD progressive risk factors in males, and differential accessi bility to heal th care, may contributeto higher prevalence of ESRD in males compared to females. Smoking and alcohol use, which are significant risk factors for CKD progression and cardiovascular disease are more common among males compared to females. ${ }^{15,16}$ Hypertension, which is one of the commonest predisposing factors for CKD, is said to bemoreprevalent in men compared to women until after menopause, when it's prevalenceeither equals that of men, or becomes higher in women. ${ }^{17,18}$ The reason for this trend is multifactorial, including neuro-hormonal and psychologic factors. ${ }^{19}$ Concerning obesity, the evidence is inconsistent; some studies have reported obesity as a risk for CKD in females but not in males ${ }^{20,21}$; while others studies havereported theopposite. ${ }^{22,23}$

Gender differences in the risk factors of CKD, cannot be generalized due to ethnic, genetic, sociocultural and environmental differences from one country to another. The aim of this study was to determine gender disparities in the risk factors for CKD in a rural population in Sub-Saharan A frica.

\section{MATERIALS AND METHOD}

This study was based on previous data obtained from a large community based cross-sectional study carried out in Ogbona, a rural community in Etsako-central local governmentarea in Edo State. ${ }^{24}$ Multi-stage cluster sampling was used to select 476 consenting adults from 142 housing units in the community, after obtaining permission from the Traditional ruler. The community has a total of 570 housing units with assigned primary health care (PHC) numbers, 142 housing units were selected systematically starting with a randomly determined house. Eligible participants per housing unit were estimated from the total adult population of 2405 as follows: $2405 / 570=4$. Each housing unit served as a cluster, and four consenting eligible participants in each housing unit were randomly recruited to achieve the sample; wherea housing unithad 4 adults, all were recruited. Socio-demographic data, relevant health, and behavioural data were collected using an adapted version of the WHO STEPS for surveillance of chronic diseases risk factors and chronic disease-specific morbidity and mortality questionnaire. ${ }^{25}$ Anthropometric measurements, clinical examinations, and laboratory 
investigations were performed by the researcher and trained assistants. Obesity was determined by measuring the height, weight, waist, hip circumference; and thereafter calculating the body mass index (BMI) and waist-hip ratio. Body fat percentage was calculated using the Deurenberg equation. ${ }^{26}$ Obesity was regarded as BMI $>30 \mathrm{~kg} / \mathrm{m}^{2}$ or Body fat percentage of $>32 \%$, for females and $>25 \%$ for males, waist circumference $>102 \mathrm{~cm}$ in males, $88 \mathrm{~cm}$ in females, WHR $>0.7$ in females and $>$ 0.9 in males. BMI was further classified according to the WHO classification ${ }^{27}$ into underweight $\left(\mathrm{BMI}<18.5 \mathrm{~kg} / \mathrm{m}^{2}\right)$, normal $\left(18.5-24.9 \mathrm{~kg} / \mathrm{m}^{2}\right)$, overweight $\left(25-29.9 \mathrm{~kg} / \mathrm{m}^{2}\right)$, obesity I (30-34.9 $\left.\mathrm{kg} / \mathrm{m}^{2}\right)$, obesity II $\left(35.9-39.5 \mathrm{~kg} / \mathrm{m}^{2}\right)$ and extreme obesity $\left(\geq 40 \mathrm{~kg} / \mathrm{m}^{2}\right)$.

Laboratory tests included, serum creatinine, and urinalysis. Subjects who had + protein on dipstick urine test were considered to have proteinuria and were re-examined after 3 months to establish persistence. A single measurement of serum creatinine was done due to the financial implications. Glomerular filtration rate (eGFR) was re-calculated using MDRD (theoriginal study ${ }^{24}$ that served as data source used the Cockcroft-Gault equation). CKD was defined as eGFR $<60 \mathrm{ml} / \mathrm{min} / 1.73 \mathrm{~m}^{2}$, and/ or the presence of persistent urinary abnormalities (proteinuria). Ethical clearance was obtained from the University of Benin Teaching Hospital Ethical Committee (Protocol number: ADM/ E.22A/ VOL.VII/ 163).

\section{DATA ANALYSIS}

Data was analyzed using SPSS statistical software package version 22 (IBM Corp., A monk, NY, USA). Continuous and categorical variables were expressed as mean \pm SD and percentages respectively. Age-adjusted gender-specific crude prevalence rates of risk factors of chronic kidney disease, and adjusted prevalence odds ratio (OR) between the exposure variables and gender were determined. All $p$ values $<0.05$ were regarded as statistically significant. The exposure variables included age, smoking, family history, use of nephrotoxic agents (such as NSAIDs, skin lightening agents, herbal remedies), proteinuria, obesity, systolic hypertension, diastolic hypertension, and diabetes.

\section{RESULTS \\ Demographics, Anthropometric and Laboratory measurements}

Four hundred and seventy-six individuals were studied; of these 315 (66.2\%) were females while male to female ratio was 1:1.9. Overall mean age was $46 \pm 17 y e a r s$, and there was no statistically significant difference between males and females with regardsto age $(46.4 \pm 19.6 y e a r s v s$.

$46.9 \pm 16.8$ years, $P=0.781$ ). The overall mean serum creatinine concentration was $0.95 \pm 0.31 \mathrm{mg} / \mathrm{dl}$. Majority of the participants had serum creatinine within normal limits (Fig 1). Overall prevalence of CKD was $14.3 \% ; 12.7 \%$ and $6.8 \%$ of males and females respectively had eGFR $<60 \mathrm{ml} / \mathrm{min}$, however this was not statistically significant $\left(X^{2}=\right.$ 3.833, $P=0.06$ ). Table 1 shows the comparison of anthropometric measurements according to gender. Males had a higher mean weight compared to females; while estimated body fat percentage (BF) and waist circumference (WC) were higher in females; these differences were all statistically significant.

\section{Risk Factors of CKD}

Table 2 shows comparison of risk factors of CKD according to gender. A significantly higher proportion of femal es compared to males, had high estimated BF (65.7\% vs. $40.9 \%, P=<0.0001)$; while females were more obese when defined with BMI, but this was not statistically significant ( $15.9 \%$ vs. $10.6 \%, P=0.127)$. Although more females were in the Obesity I and II categories i.e. BMI $>30 \mathrm{~kg} / \mathrm{m}^{2}$, significantly more males were overweight compared to females $(42.2 \%$ and $28.9 \%$ respectively, $\mathrm{P}=0.004)$; all extremely obese individualswerefemales. Theprevalenceof central obesity was much higher in females than males (43.2\% and 4.3\%, P $=<0.0001)$, and high WHR was more prevalent among women $(99.7 \%$ vs. $73.3 \%$, $P=<0.0001)$. seeTable 2 .

A higher proportion of females compared to males used skin-lightening agents $(7.9 \%$ vs. $6.8 \%$, $\mathrm{p}=0.405)$. More males than females drank alcohol ( $56 \%$ vs. $9.2 \%, P=<0.0001$ ), and no female smoked. Use of NSAIDs and herbal medications were commoner in females compared to males but did not reach statistical significance. Similarly, systolic 
Table 1: A nthropometric Indices of the 476 Subjects A ccording to $\mathrm{G}$ ender

\begin{tabular}{|c|c|c|c|c|}
\hline & $\begin{array}{c}\mathrm{ALL} \\
\text { Mean } \pm \mathrm{SD}\end{array}$ & $\begin{array}{c}\text { MALES } \\
\text { Mean } \pm \text { SD }\end{array}$ & $\begin{array}{l}\text { FEMALES } \\
\text { Mean } \pm \text { SD }\end{array}$ & $\begin{array}{c}\text { Mean Difference } \\
95 \% \mathrm{Cl}\end{array}$ \\
\hline Weight $(\mathrm{kg})$ & $65.2+12.3$ & $68.9 \pm 11.5$ & $63.3 \pm 12.3$ & $5.6(3.3,7.9)^{*}$ \\
\hline BF (\%) & $38.6 \pm 8.6$ & $30.6 \pm 9.1$ & $32.4 \pm 8.4$ & $-1.8(-3.4,-0.2)^{*}$ \\
\hline $\mathrm{BMI}\left(\mathrm{kg} / \mathrm{m}^{2}\right)$ & $25.0 \pm 4.7$ & $25.2 \pm 3.9$ & $25.0 \pm 5.1$ & $0.2(-0.7,1.1)$ \\
\hline $\begin{array}{l}\text { Waist } \\
\text { Circumference(cm) }\end{array}$ & $86.2 \pm 11.1$ & $84.7 \pm 9.1$ & $86.9 \pm 12.1$ & $-2.2(-4.3,-0.1)^{*}$ \\
\hline Waist: Hip Ratio (WHR) & $0.9 \pm 0.1$ & $0.9 \pm 0.1$ & $0.9 \pm 0.1$ & $0.0(0.0,0.0)$ \\
\hline
\end{tabular}

and diastolic hypertension were more prevalent in females but was not statistically significant (32.1\% vs. $31.7 \%$ and $26.0 \%$ vs. $24.2 \%$ for systolicand diastolic hypertension respectively).

Diabetes mellitus was commoner in mal es but was not statistically significance ( $2.5 \%$ and $1.9 \%, \mathrm{P}=0.677$ ). Initial overall prevalence of proteinuria was $4.4 \%$ but reduced to $3.6 \%$ after re-assessment at 3-months. Proteinuria was commoner in males compared to females but was just short of statistical significance $(6.2 \%$ and $2.5 \%, p=0.054)$.

\section{IndependentR isk Factors A ssociated with Sex}

Table 3 shows the independent risk factors associated with sex and age. The odds of females having central obesity are 16.7 times the odds of males having central obesity; similarly, the odds of females having high BF are 2.7 times the odds of males having high BF. Females had 122-fold the odds of men having high WHR. Theodds of drinking alcohol are92\% less compared to males. Theseobservationswere

Table 2: Risk Factors A ssociated with Sex

\begin{tabular}{|c|c|c|c|c|c|c|c|}
\hline \multirow[t]{3}{*}{ Factors } & & & \multicolumn{4}{|c|}{ Sex } & \multirow[t]{3}{*}{ P value } \\
\hline & \multicolumn{2}{|c|}{ Total } & \multicolumn{2}{|c|}{ Male } & \multicolumn{2}{|c|}{ Female } & \\
\hline & $n=476$ & $\%$ & $n=161$ & $\%$ & $n=315$ & $\%$ & \\
\hline $\begin{array}{l}\text { Family History of } \\
\text { HTN }\end{array}$ & 38 & 7.9 & 12 & 7.4 & 26 & 8.2 & 0.859 \\
\hline Family History of DM & 39 & 8.2 & 13 & 8.1 & 27 & 8.6 & 0.155 \\
\hline Cigarette smoking & 19 & 3.9 & 19 & 11.8 & 0 & 0.0 & $\lessdot 0.0001^{*}$ \\
\hline Alcohol use & 111 & 23.3 & 90 & 55.9 & 21 & 6.7 & $<0.0001^{*}$ \\
\hline $\begin{array}{l}\text { Use of Skin lightening } \\
\text { agents }\end{array}$ & 36 & 7.6 & 11 & 6.8 & 25 & 7.9 & 0.405 \\
\hline Use of NSAIDS & 132 & 27.7 & 40 & 24.8 & 92 & 29.2 & 0.315 \\
\hline Herbal Medicine Use & 111 & 23.3 & 34 & 21.1 & 77 & 24.4 & 0.425 \\
\hline Diabetic & 10 & 2.1 & 4 & 2.5 & 6 & 1.9 & 0.739 \\
\hline Systolic Hypertension & 152 & 31.9 & 51 & 31.7 & 101 & 32.1 & 1.000 \\
\hline $\begin{array}{l}\text { Diastolic } \\
\text { Hypertension }\end{array}$ & 121 & 25.4 & 39 & 24.2 & 82 & 26.0 & 0.738 \\
\hline Obesity (BF) & 273 & 57.3 & 66 & 40.9 & 207 & 65.7 & $\lessdot 0.0001^{*}$ \\
\hline Obesity (BMI) & 67 & 14.1 & 17 & 10.6 & 50 & 15.9 & 0.127 \\
\hline Central obesity & 143 & 30.0 & 7 & 4.3 & 136 & 43.2 & $\lessdot 0.0001^{*}$ \\
\hline Proteinuria & 18 & 3.8 & 10 & 6.2 & 8 & 2.5 & 0.054 \\
\hline Waist-Hip ratio & 432 & 90.7 & 118 & 73.3 & 314 & 99.7 & $\lessdot 0.0001^{*}$ \\
\hline
\end{tabular}


Table 3: Independent Risk Factors A ssociated with Sex and Age

\begin{tabular}{|c|c|c|c|c|}
\hline \multirow[b]{3}{*}{ Alcohol use } & \multicolumn{2}{|c|}{ Univariate analysis } & \multicolumn{2}{|c|}{ M ultivariate analysis } \\
\hline & Unadjusted OR $(95 \% \mathrm{Cl})$ & P value & A djusted OR (95 Cl \%) & $P$ value \\
\hline & & & & \\
\hline Male & 1 & & 1 & \\
\hline Female & $0.08(0.05-0.13)$ & $<0.0001$ & $0.08(0.05-0.13)$ & $\varangle 0.0001^{*}$ \\
\hline Age & $0.99(0.98-1.01)$ & 0.921 & $1(0.98-1.01)$ & 0.975 \\
\hline \multicolumn{5}{|c|}{ Use of Skin lightening agents } \\
\hline Male & 1 & & 1 & \\
\hline Female & $0.08(0.049-0.131)$ & & $1.431(0.659-3.108)$ & 0.365 \\
\hline Age & 0.927(0.9-0.954) & $<0.0001$ & $0.925(0.898-0.953)$ & $<0.0001 *$ \\
\hline \multicolumn{5}{|l|}{ Herbal use } \\
\hline Male & 1 & & 1 & \\
\hline Female & $1.21(0.77-1.92)$ & 0.407 & $1.23(0.77-1.95)$ & 0.392 \\
\hline Age & $1.02(1.01-1.04)$ & $\varangle 0.0001$ & $1.02(1.01-1.04)$ & $\varangle 0.0001^{*}$ \\
\hline \multicolumn{5}{|l|}{ NSAID use } \\
\hline Male & 1 & & 1 & \\
\hline Female & $1.25(0.81-1.92)$ & 0.315 & $1.26(0.81-1.96)$ & 0.306 \\
\hline Age & $1.02(1.01-1.04)$ & $<0.0001$ & $1.02(1.01-1.04)$ & $\Varangle 0.0001^{*}$ \\
\hline \multicolumn{5}{|c|}{ Systolic Hypertension } \\
\hline Male & 1 & & 1 & \\
\hline Female & $1.08(0.70-1.69)$ & 0.707 & 1.08(0.67-1.73) & 0.743 \\
\hline Age & $1.04(1.03-1.06)$ & $<0.0001$ & $1.044(1.03-1.06)$ & $<0.0001 *$ \\
\hline \multicolumn{5}{|c|}{ Diastolic Hypertension } \\
\hline Male & 1 & & 1 & \\
\hline Female & $1.02(0.68-1.53)$ & 0.932 & $1.02(0.66-1.59)$ & 0.912 \\
\hline Age & $1.05(1.03-1.062)$ & $<0.0001$ & $1.05(1.03-1.06)$ & $<0.0001^{*}$ \\
\hline \multicolumn{5}{|l|}{ Obesity (BF) } \\
\hline Male & 1 & & 1 & \\
\hline Female & $2.759(1.866-4.078)$ & $\Varangle 0.0001$ & $4.162(2.514-6.891)$ & $\Varangle 0.0001 *$ \\
\hline Age & $1.084(1.068-1.101)$ & $\lessdot 0.0001$ & 1.09(1.072-1.107) & $<0.0001 *$ \\
\hline \multicolumn{5}{|c|}{ Central Obesity } \\
\hline Male & 1 & & 1 & \\
\hline Female & $16.715(7.589-36.814)$ & $\lessdot 0.0001$ & 18.174(8.163-40.459) & $\varangle 0.0001 *$ \\
\hline Age & $1.02(1.008-1.031)$ & 0.001 & $1.025(1.012-1.038)$ & $<0.0001^{*}$ \\
\hline \multicolumn{5}{|l|}{ Proteinuria } \\
\hline Male & 1 & & 1 & \\
\hline Female & $0.393(0.152-1.017)$ & 0.054 & $0.398(0.153-1.034)$ & 0.059 \\
\hline Age & $1.028(1-1.056)$ & 0.047 & $1.027(1-1.054)$ & 0.05 \\
\hline \multicolumn{5}{|c|}{ Waist-Hip ratio } \\
\hline Male & $\begin{array}{ll}1\end{array}$ & & $\begin{array}{ll}1 & 1\end{array}$ & \\
\hline Female & 114.424(15.581-840.33) & $<0.0001$ & $122.926(16.623-909.024)$ & $<0.0001^{*}$ \\
\hline Age & $1.045(1.023-1.066)$ & $\Varangle 0.0001$ & $1.046(1.023-1.069)$ & $<0.0001 *$ \\
\hline
\end{tabular}

$\mathrm{NA}=$ Not applicable 


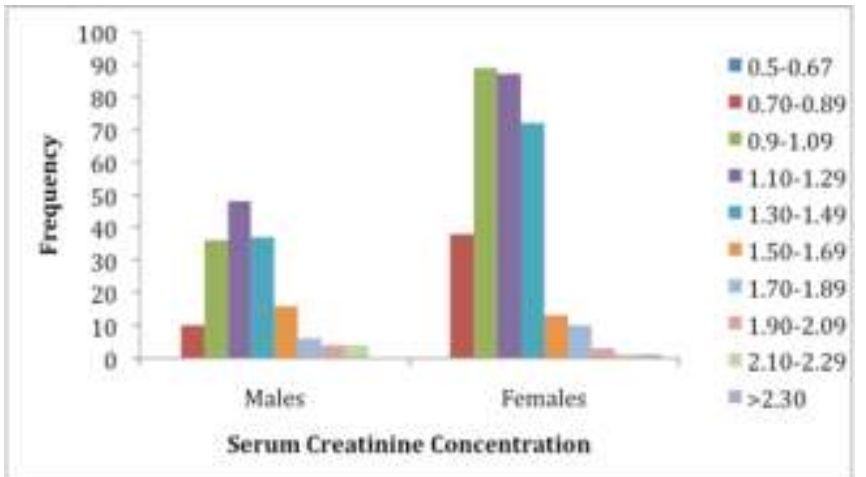

statistically significant in both univariate and multivariateanalysis.

The odds for using skin lightening agent was 7\% less with every one-year increase in age; while the odds for use of herbal medication and NSAIDs was $2 \%$ greater with every one-year increase in age 1.025. Every one-year increase in age is associated with a $4 \%$ and $5 \%$ greater risk for systolic and diastolic hypertension respectively. Every one-year increase in age is associated with $9 \%, 5 \%$, and $2 \%$ greater odds for having high body fat, high WHR and central obesity respectively. These observations were statistically significant in both univariateand multivariateanalysis.

\section{DISCUSSION}

This study showed no significant gender differences in theprevalence of CKD although more females had CKD, supporting previous reports from Nigeria and other parts of the world. ${ }^{5-8}$ There was a preponderance of females compared to males in this study reflecting the gender distribution in thecommunity studied. ${ }^{28}$ Other possiblereasonsfor the female preponderance observed include unavailability of somemen who leavehomeearly to their farms and businesses; some refused to have their blood samples collected due to the anxiety of diagnosing an illness. This gender distribution is however similar to results from a systematic a review of CKD prevalence in Nigeria; ${ }^{29}$ the researchers observed consistently more females than males in the six studies reviewed. Similarly, the systematic review of the burden of CKD in SubSaharan by Stanifer et $\mathrm{al}^{2}$, observed more female than male participants (68\% vs. $42 \%$ ). Thesefigures generally suggest that females are more disposed, and availablefor voluntary health screening.
Regarding anthropometric measurements differences were observed across the gender. Although Obesity classes I and II were more prevalent in females, mean weight was higher in males than females, and moremales wereclassified as overweight using the BMI. This trend was also reported from the NHANES study and other researchers ${ }^{30,31}$ and may reflect the bias of using BM I as a measure of excess fat accumulation in men who have large muscle mass and skeletal frame. ${ }^{32}$ Morbid obesity was only found in females, and this corroborates with data from the NHANES study ${ }^{30}$, in which $9.9 \%$ of women compared to $5.5 \%$ of males were morbidly obese. This probably reflects a combination of hormonal factors, sedentary lifestyle and unhealthy eating habits in females compared to males. ${ }^{33} \mathrm{M}$ en in thepopulation studied are mostly active small-scale farmers and commercial motorbikeriders, whilethefemales are traders and home-keepers suggesting that the femalesweremoresedentary.

As was expected females had greater odds for high BF compared to males; ${ }^{34}$ mean BF was higher in females, and obesity defined by BF was significantly higher in females compared to males. Conversely, A min et al ${ }^{35}$, studied a high-risk A sian population and observed that obesity defined using BF (measured by bioimpedance analysis) was $82.3 \%$ and $79.5 \%$ in males and females respectively, this difference was however not statistically significant. In the current study BF was estimated with the Deurenberg equation that has an estimation error of $4 \%$ in elderly men and women ${ }^{26}$ and is not validated in Africans; however, our observations corroborate the general knowledge that females have more body fat compared to males. More accurate methods of measuring body fat include bio-impedance analysis, dual energy $x$ ray absorptiometry (DEXA) and underwater weighing, but would have been cumbersome for population screening.

The odds for central obesity, and high WHR were greater in females compared to males. This may be dueto hormonal factors, previous pregnancies, and lifestyle. Other researchers have similarly reported higher proportion of central obesity in females compared to males in general population. ${ }^{36-38}$ Beigh 
et al studied hospitalised patients with diagnosis of myocardial infarction, renal and liver disease, as well as control without these diagnoses, and found central obesity in $63.5 \%$ of females compared to $45 \%$ in males. ${ }^{36}$

Use of nephrotoxins like NSAIDS, herbal remedies and skin bleaching weregenerally common in both genders, although the use of skin lighteners was slighter commoner in females. The practice of skin bleaching is common among blacks throughout the world, although most reports are from African countries. ${ }^{39,40}$ The reason behind this is linked to deep historical, economic, socio-cultural and psychosocial factors. ${ }^{41,42}$ Although this habit is condemned in many African countries, it remains common, due to ineffective regulation of the availability and accessibility of these harmful cosmetic creams; additionally, majority of users are ignorant of the harmful effects, while others overlook them. The regular use and/ or abuse of NSA IDs is common among older women who tend to suffer pain from musculoskeletal and arthritic diseases probably due to excess weight gain, and wear and tear. Men in the rural community who were studied, habitually ingest a mixture of NSAIDs as remedy for body pains due to their labour intensive jobs (farmers, labourers, bikeriding). The use of local herbal remedies is also commonplace in Nigeria and many African countries ${ }^{43}$ where they are believed to cure a range of illnesses; unfortunately, these remedies are mostly unstandardised and potentially harmful to thekidneysand other organs. ${ }^{44}$

Smoking and alcohol use were commoner in males as was expected, and is corroborated by other studies. Socio-cultural and religious perceptions often deter females from engaging in these habits. Smoking is a risk factor for progression of CKD and for cardiovascular disease. ${ }^{13,45}$ Some authors have suggested that smoking as well as other factors may explain the higher rate of CKD progression in males compared to pre-menopausal females. ${ }^{46,47} \mathrm{Alcohol}$ has also been associated with CKD and progression of the disease; although this study showed that significantly more men drank alcohol, up to $9.2 \%$ of females drank alcohol regularly. One study reported an increased risk for hypertension in both males and females who drank alcohol, this risk was observed at 4 drinks per day for women and 1 drink per day in men. ${ }^{48}$ The implication is that alcohol use also increases the risk for CKD through hypertension, which is a leading aetiology of CKD and even minimal use ( $>1$ drink per day) in men, should bediscouraged.

Dipstick proteinuria was commoner in males, although did not reach statistical significance. Experimental studies suggest that proteinuria and glomerular disease develop more in naturally ageing males than females, mainly due to the protective effect of female sex hormones, higher levels of nitric oxide in females, and glomerulomegaly in mal es compared to females. ${ }^{49.52}$ Gender differences regarding proteinuria is not consistent in the literature, while some studies reported a male preponderance, others have either reported female preponderance or no difference. The technique of detecting or measuring proteinuria varies across studies, and this may significantly explain theseinconsistencies. Majority of earlier studies relied on one-time dipstick test or 24hr urine collections while newer studies utilize albumin: creatinine ratio. Although dipstick tests are sufficiently sensitive and specific for screening non-diabetic population for proteinuria; ${ }^{53}$ the timing, frequency, and manner of urine collection may besignificant sources of error.

Finally, this study observed that increasing agewas associated with greater odds for hypertension, high body fat, high WHR and central obesity. These observations confirm the general knowledge that aging is associated with higher risk of cardiovascular disease.

This study is based on one of the few large sample community-based study on epidemiology of CKD in Nigeria. Limitations include the one-time estimation of GFR, however, all patients with urinary abnormalities were re-assessed after three months to establish the persistence of urinary abnormalities. Only individuals with GFR $<60 \mathrm{ml} / \mathrm{min}$ or eGFR $>60 \mathrm{ml} / \mathrm{min}$ with persistent urinary abnormalities were regarded as having CKD. Some risk factors for CKD were not evaluated in thisstudy. 


\section{CONCLUSION}

This study shows gender differences regarding some risk factors of CKD. The odds for central obesity, high WHR, high body fat percentages are significantly greater in females; while smoking, alcohol use, and overweightness, are commoner in males. Increasing age was associated with greater

odds for systolic hypertension, diastolic hypertension, high body fat, high WHR and central obesity; while the odds of using skin lightening agent is less with increasing age. These findings should inform future public health education efforts, and subsequent heal th interventions.

9. Ghulmiyyah L, Sibai B. Maternal mortality from

\section{REFERENCES}

1. Lozano R, Naghavi M, Foreman K, Lim S, Shibuya K, et al. Global and regional mortality from 235 causes of death for 20 age groups in 1990 and 2010: a systematic analysis for the Global Burden of Disease Study 2010. Lancet 2012; 380 (9859): 2095-128.

2. Stanifer JW, Jing B, Tolan S, et al. The epidemiology of chronic kidney disease in subSaharan Africa: a systematic review and metaanalysis. Lancet G lob H ealth 2014; 2: e174-81

3. Kaze AD, Ilori T, Jaar BG, Echouffo-Tcheugui JB. Burden of chronic kidney disease on the African continent: a systematic review and meta-analysis. BMC Nephrol. 2018 Jun 1;19(1):125. doi: 10.1186/ s12882-018-0930-5. PMID: 29859046; PMCID: PMC5984759.

4. Zhang L, Wang F, Fuo L, Zhou Y, Shi Y, Li G et al. Prevalence and factors associated with CKD: a population study from Beijing. A $\mathrm{m} J$ of Kidney $D$ is. 2008;51(3):373-84.

5. Egbi OG, Okafor UH, Miebodei KE, Kasia BE, Kunle-Olowu OE, UnuigbeEl. Prevalence and correlates of chronic kidney disease among civil servants in Bayelsa state, Nigeria. N iger J Clin Pract 2014; 17:602-7

6. Ulasi II, Ijoma CK, Onodugo DO, et al: Towards prevention of chronic kidney disease in Nigeria: a community - based study in Southeast Nigeria. Kid. Int. Suppl; 3:( 2): 195- 201, 2013

7. United States Renal Data System. 2015 USRDS annual data report: Epidemiology of kidney disease in the United States. National Institutes of Health, National Institute of Diabetes and Digestive and Kidney Diseases. 2015. Available at: http:/ / www.usrds.org/ adr.aspx. A ccessed: 9June2018.

8. Bikbov B, Perico N, Remuzzi G: Disparities in Chronic Kidney Disease Prevalence among Males and Females in 195 Countries: Analysis of the Global Burden of Disease 2016 Study. Nephron 2018: 313-318. preeclampsia/ eclampsia. Semin Perinatol. 2012; 36(1):56-9.

10. World Health Organization (2004). "Annex Table2: Deaths by cause, sex and mortality stratum in WHO regions, estimates for 2002" (PDF). The world health report 2004 - changing history. Accessed A pril 4, 2019

11.Kastarinen $M$, Juutilainen $A$, Kastarinen $H$, Salomaa V, Karhapaa P, Tuomilehto J et al. Risk factors for end-stage renal disease in a communitybased population: 26-year follow-up of 25821 men and women in eastern Finland. J Intern $M$ ed. 2010;267(6):612-20.

12. Haroun MK, Jaar BG, Hoffman SC, Comstock GW, Klag MJ, Coresh J. Risk factors for chronic kidney disease: a prospective study of 23,534 men and women in Washington County, Maryland. J A m Soc N ephrol. 2003;14(11):2934-41.

13. Wakai K, Nakai S, Kikuchi K, Iseki K, Miwa N, Masakane I et al. Trends in incidence of end-stage renal diseasein Japan, 1983- 2000: age-adjusted and age-specific rates by gender and cause. $N$ ephrol Dial Transplant. 2004;19(8):2044-52.

14. Neugarten J, A charya A, Silberger SR. Effect of gender on the progression of non-diabetic renal disease a meta-analysis. J Am Soc Nephrol. 2000;11(2):319-29

15. A nthony JC, Echeagaray-Wagner $F$. Epidemiologic analysis of alcohol and tobacco use. A I cohol Research \& H ealth 2000; 24(4):201-208.

16. Iseki K. Gender differences in chronic kidney disease. Kidney Int. 2008;74(4):415-7.

17. Kearney PM, Whelton M, Reynolds K, Muntner $\mathrm{P}$, Whelton PK, He J. Global burden of hypertension; analysis of worldwide data. Lancet. 2005; 365:217-223

18. Ong KL, Tso AWK, Lam KS, Cheung BM. Gender differences in BP control and cardiovascular risk factors in Americans with diagnosed hypertension. Hypertension. 2008; 


\section{1:1142-1148}

19. Lima R, Wofford M, Reckelhoff JF. Hypertension in postmenopausal women. Curr H ypertens Rep. 2012; 14(3): 254-260

20. Shankar A, Leng C, Chia KS, Koh D, Tai ES, Saw SM et al. Association between body mass index and chronic kidney disease in men and women: population-based study of Malay adults in Singapore. N ephrol D ial T ransplant. 2008; 23(6):19108.

21. Iseki K, Ikemiya Y, Kinjo K, Inoue T, Iseki C, Takishita S. Body mass index and the risk of development of end-stage renal disease in a screened cohort. Kidney Int. 2004;65(5):1870-6.

22. Cohen E, Fraser A, Goldberg E, M ilo G, Garty M, Krausel. Association between the body mass index and chronic kidney disease in men and women. A population-based study from Israel. Nephrol Dial Transplant. 2013; 28(Suppl 4):130-5

23. Komura H, Nomura I, Kitamura K, Kuwasako $K$, KatoJ. Gender differencein relationship between body mass index and development of chronic kidney disease. BM C R es N otes. 2013; 6(1):463

24. Okoye OC, Oviasu E, Ojogwu LI. Prevalence of CKD and its risk factors amongst adults in a rural population in Edo state. J USChina Med Sci. 2011; 8: 471-481

25.World Health Organisation STEPwise approach to chronic disease risk factor surveillance (STEPS). W H O G eneva. A vailable a t www.who.Int/ chp/ steps/ STEPS_Instrument.pdf. Accessed June2008

26. Deurenberg P, Yap M, Van Staveren WA. Body mass index and percent body fat: a meta analysis among different ethnic groups. Int J 0 bes Relat M etab D isord 1998; 22: 1164-1171

27. Obesity: Preventing and managing the Global Epidemic - Report of a WHO Consultation on Obesity, 3-5 June 1997, Geneva, WHO/ NUT/ NCD/ 98.1.

28. National and State Provisional Totals 2006 Census. Federal Republic of Nigeria official Gazette 2007; 94: B184.

29. Chukwuonye II, Ogah OS, Anyabolu EN, Ohagwu KA, N wabuko OC, Onwuchekwa U, et al. Prevalence of chronic kidney disease in Nigeria: systematic review of population-based studies. Int J N ephrol R enovasc D is. 2018; 11:165-172

30. Fryar CD, Carroll MD, Ogden CL. Prevalence of overweight, obesity, and extreme obesity among adults aged 20 and over: United States, 1960-1962 through 2011-2014. National Center for Health Statistics Data, Health E-Stats, July 2016. A vailable a

https:/ / www.cdc.gov/ nchs/ data/ hestat/ obesity adult 13 14/ obesity adult 13 14.htm https:// www.niddk.nih.gov/ disclaimers. Accessed A pril 3rd 2019.

31. Fabbian F, Bendani PL, Rizzioli E, Molino C, Pala M, De Giorgi A et al. Risk factors for renal disease and urinary abnormalities in men and women: data from the world kidney day in the provinceof Ferrara, Italy. R en F ail . 2013;35 (4):440-5.

32. NievesJW, Formica C, Ruffing J, Zion M, Garrett P, Lindsay R, Cosman F. Males have larger skeletal size and bone mass than females, despite comparable body size. L Bone M iner Res. 2005; 20(3):529-35.

33. Committee Opinion No. 591: Challenges for Overweight and Obese Women. The American College of Obstetricians and Gynecologists Committee on Health Care for Underserved Women, Obstet Gynecol 2014. Available from https:/ / www.m.acog.org. A ccessed $3^{\text {rd }}$ A pril 2019

34. QuickStats: Mean Percentage Body Fat,* by Age Group and Sex --- National Health and Nutrition Examination Survey, United States, 1999--2004†". cdc.gov. National Health and Nutrition Examination Survey, 1999--2004. Available at . Accessed A pril 2019.

35. Amin $F$, Fatima SS, Islam N, Gilani AH. Prevalence of obesity and overweight, its clinical markers and associated factors in a high risk SouthAsian population. BM C O bes. 2015; 2:16.

36. Beigh $\mathrm{SH}$, Jain S. Prevalence of metabolic syndrome and gender differences. Bioinformation. 2012; 8(13): 613-16.

37. Sabir A A , Jimoh A, I wuala SO, I sezuoSA, Bilbis LA, A minu KU, et al.? Metabolic syndromein urban city of North-Western Nigeria: prevalence and determinants. The Pan A frican M edical Journal. 2016; 23:19.

38. Akhter O, Fiazuddin F, Shaheryar A, et al. Central adiposity is significantly higher in female compared to male in Pakistani type 2 diabetes mellitus patients. Indian Journal of Endocrinology and M etabolism. 2015;19(1):72-76. 
39. Benn EKT, Alexis A, Mohamed N, Wang Y-H, Khan IA, Liu B. Skin Bleaching and Dermatologic Health of African and Afro-Caribbean Populations in the US: New Directions for Methodologically Rigorous, Multidisciplinary, and Culturally SensitiveResearch. 2016;6(4):453-459.

40. Ajose FO. Consequences of skin bleaching in Nigerian men and women. Int J Dermatol. 2005 Oct;44Suppl 1:41-3.

41. Charles CAD. Skin bleaching, self-hate, and black identity in Jamaica. J Black Stud. 2003; 33(6):711-728.

42. DadzieOE, PetitA. Skin bleaching: highlighting themisuse of cutaneous depigmenting agents.J Eur A cad D ermatol V enereol JEA D V . 2009;23(7):741-750 43. Luyckx VA, Naicker S. Acute kidney injury associated with the use of traditional medicine. N atureClinical PracticeN ephrol 2008; 4: 664-667

44. Falodun A. Herbal Medicine in AfricaDistribution, Standardisation, and Prospects. Res J Phytochem 2010; 4(3): 154-161

45. Elihimas Junior UF, Elihimas H C, Lemos V M, Leão M, Sá M P, Franca E. Smoking as risk factor for chronic kidney disease: systematicreview. Brazilian Journal of N ephrology 2014;36(4): 519-528

46. Briganti EM, Branley P, Chadban SJ, Shaw JE, McNeil JJ, Welborn TA, Atkins RC. Smoking is associated with renal impairment and proteinuria in the normal population: The AusDiab kidney study. Australian Diabetes, Obesity and Lifestyle Study. A mJ Kidney D is 2002; 40:704- 712.

47. Orth SR, Ritz E: Adverse effect of smoking on renal function in thegeneral population: A remen at higher risk? A m J Kidney D is 2002;40:864- 866.

48. Sesso HD, Cook NR, Buring JE, Manson JE, Gaziano JM. Alcohol consumption and the risk of hypertension in women and men. Hypertension. 2008A pr;51(4):1080-7.

49. Baylis C. Age-dependent glomerular damagein therat. Dissociation between glomerular injury and both glomerular hypertension and hypertrophy. Male gender as a primary risk factor. J Clin Invest 199; 94: 1823-1829.

50. Davidoff M, Caffier H, and Schiebler TH. Steroid hormone binding receptors in the rat kidney. $\mathrm{H}$ istochemistry 1980; 69: 39-48.

51. Gafter U, Ben-Bassat M, and Levi J. Castration inhibits glomerular hypertrophy and proteinuria in uninephrectomized malerats. Eur J Clin Invest 1990; 20: 360-3651990.

52.Verghan MG, Attia DMA, Koomans HA, Joles JA. Malegender increases sensitivity to proteinuria induced by mild NOS inhibition in rats: role of sex hormones. Am J Physiol Renal Physiol 2000; 279: 664-670.

53. Johnson DW. Global Proteinuria Guidelines: Are we nearly there yet? Clin Biochem R ev 2011; 32: 89-95

Cite this article as: $\mathbf{O}$ koye $\mathbf{O C}$, Gender Disparity In Risk Factors For Chronic Kidney Disease In A Rural Community In Southern Nigeria KJMS 2020; 14(1): 62 - 71. 